\title{
The Morphotaxonomy and Distribution of the Genus Sargassum C. Agardh (Fucales, Phaeophyta) from Kampani Coastal Areas
}

\author{
Hsu Mon Oo ${ }^{1}$, Chaw Thiri Pyae Phyo Aye ${ }^{2}$, Mya Kyawt Wai ${ }^{3 *}$, Soe Pa Pa Kyaw ${ }^{3}$, U. Soe-Htun ${ }^{4}$
}

${ }^{1}$ MSc Candidate, Department of Marine Science, Mawlamyine University

${ }^{2}$ Demonstrator, Department of Marine Science, Mawlamyine University

${ }^{3}$ Assistant Lecturer, Department of Marine Science, Mawlamyine University

${ }^{4}$ Professor \& Head, Department of Marine Science, Mawlamyine University

*Corresponding Author: Mya Kyawt Wai, Assistant Lecturer, Department of Marine Science, Mawlamyine University, Myanmar; E-mail: mrakyawtwai@gmial.com

\begin{abstract}
Three species of Sargassum belonging to the Sargassum subgenus Sargassum (Fucales, Phaeophyta) collected from the Kampani coastal areas- Thabawseik and southern Kampani from October 2012 to March 2013, had been identified as Sargassum swartzii (Turner) C. Agardh and S. cervicorne Greville under the section Binderiana and S. plagiophyllum C. Agardh (with or without stolons) under the section Polycystae based on a detailed account of morphologies of vegetative and reproductive structures of the plants. Sargassum plagiophyllum C. Agardh (with or without stolons) is the most common species occurring in the two study areas. The growth patterns in the development of furcate cauline leaf, dwarfs of main branch as well as different orders of branches, leaves, vesicles and receptacles of Sargassum swartzii (Turner) C. Agardh and S. cervicorne Greville under Sargassum section Binderiana was recorded. In addition, $S$. cervicorne Greville was firstly reported from Kampani coastal areas. Moreover, the simple cauline leaf, dwarfs of main branch or stolons as well as different orders of branches, leaves, vesicles and receptacles of S. plagiophyllum C. Agardh (with or without stolons) under Sargassum section Polycystae belonging to the S. subgenus Sargassum from Kampani coastal areas was also recorded.
\end{abstract}

Keywords: Binderiana; Fucales; Growth patterns; Morphology; Phaeophyta; Phytogeographic distribution; Polycystae; Sargassum, S. cervicorne, S. plagiophyllum, S. swartzii, taxonomy.

\section{Introduction}

The brown algal genus Sargassum which represents 929 species names of which 335 are currently accepted taxonomically, are the most abundant plants in various major marine geographical regions from Indo-Pacific to the Atlantic Oceans, covering temperate, sub-tropical and tropical regions of the world oceans ${ }^{[1,2]}$. However, less than $40 \%$ are recognized as current, identifying a species is often a difficult task ${ }^{[3]}$. Morphology and taxonomy of the genus Sargassum are still complex and variable due to many problems of phenotypic variations caused by polymorphisms and polyphenisms as well as genetic differences among populations ${ }^{[4-8]}$. Sargassum species are economically important, especially in Asian countries where they are exploited by agro-food, textile, cosmetic and pharmaceutical industries. It can be utilized as a source of phycocolloids, in particular alginate, which is used in the textile industry in Indonesia and Vietnam. It is also used in vegetable soup. Young shoots also form a common ingredient of fish dishes in northern Philippines ${ }^{[9]}$. Moreover,
Received date: July 28, 2015

Accepted date: Sep 8, 2015

Published date: Sep 16, 2015

Citation: Mya Kyawt, W., et al. The Morphotaxonomy and Distribution of the Genus Sargassum C. Agardh (Fucales, Phaeophyta) from Kampani Coastal Areas. (2015) J Marine Biol Aquacult 1(2): 1- 12.

the genus Sargassum showed antibacterial or antiviral activity ${ }^{[10-12]}$ as well as antioxidant and antifungal activities $^{[13-15]}$.

In Myanmar, the genus Sargassum known as "Leik-Sar-Phatt" or "Kyauk-Pann" in local name, grows luxuriantly along the Rakhine and Tanintharyi Coastal Regions and subjects to the lower intertidal and subtidal zones in winter and summer months. Kyaw Soe et $\mathrm{al}^{[16]}$ recorded a total of 22 species of Sargassum. Soe-Htun $^{[17]}$ described fifteen species of Sargassum, namely S.affin. trichophyllum (Kutzing) C. Kuntze, $S$. affin. salicifoloides Yamada, $S$. affin. kasyotense Yamada, S. affin. tenerrimum J. Agardh, S. affin. carpophyllum J. Agardh, S. ilicifolium (Turner) C. Agardh, S. cristaefolium C. Agardh, $S$. duplicatum Bory, $S$. swartzii (Turner) C. Agardh, S. plagiophyllum (Mertens) C. Agardh, $S$. polycystum C. Agardh, S. herporhi- 
zum Setchell and Gardner, S. sp. 1, S. sp.2 and S. sp.3.in details Recently, Soe-Htun et al ${ }^{[18]}$ reported the sequential processes of development of stolons and branches as well as leaves, vesicles, and receptacles of Sargassum polycystum C. Agardh and S. plagiophyllum (Mertens) C. Agardh (Sargassum section Polycystae) from Myanmar.

The purposes of this study are: 1) to know the morphotaxonomy of the genus Sargassum spp.; and 2) to elucidate the biodiversity and distribution of Sargassum spp. in Kampani coastal areas.

\section{Materials and Methods}

The specimens examined were collected from the intertidal and sub tidal zones of the Southern Kampani (Lat. $14^{\circ}$ $02^{\prime} \mathrm{N}$, Long. $98^{\circ} 04^{\prime} \mathrm{E}$ ) and Thabawseik (Lat. $14^{\circ} 05^{\prime} \mathrm{N}$, Long. $98^{\circ} 05^{\prime} \mathrm{E}$ ) coastal areas in Longlone Township of Taninthayi Region from 2012 to 2013 (Figure 1). All collected specimens were washed with seawater to remove the adhering other materials and contaminants and preserved in 5\% formalin (40\% formaldehyde) solution in seawater for a detailed investigation on external and internal morphologies of the materials. The herbarium sheets were prepared and deposited at the Herbarium of Department of Marine Science, Mawlamyine University (MMB). The external and internal characteristics of vegetative and reproductive structures used in the identification of the plants were also recorded and photographed by using digital camera, under the compound and dissecting microscopes. The sections of the samples were made by hand, using razor blades and were stained with $1 \%$ aniline blue or $1 \%$ acid fuchsin. Microscopic measurements of the specimens were recorded by using the calibrated ocular micrometer. Digital photographs were processing in Photoshop CS3. Identification of specimens was made, mainly based on the following taxonomic references: Soe-Htun ${ }^{[17]}$, Mattio et $a l^{[8]}$ Guiry et $a l^{[2]}$. The local distribution of each taxon derived primarily from the reference collection of herbarium specimens examined. Phytogeography and potential uses of these algae were acknowledged from the worldwide literature records.

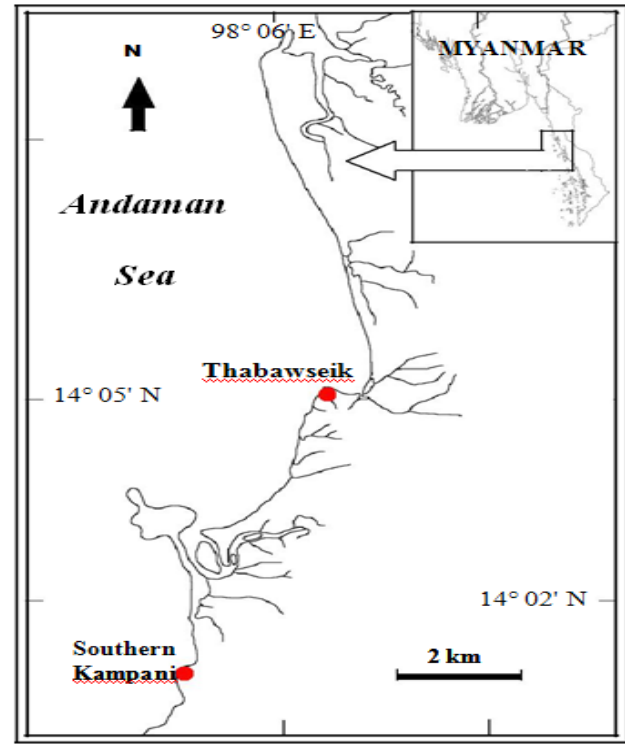

Figure 1: Map showing the two collection sites of the genus Sargassum from Kampani coastal areas.

\section{Results}

Three species of Sargassum belonging to the Sargassum subgenus Sargassum (Fucales, Phaeophyta) collected from the Kampani coastal areas- Thabawseik and southern Kampani from October 2012 to March 2013, had been identified as Sargassum swartzii (Turner) C. Agardh and S. cervicorne Greville under the section Binderiana and S. plagiophyllum C. Agardh (with and without stolons) under the section Polycystae based on a detailed account of morphologies of vegetative and reproductive structures of the plants.

A classification system of the genus Sargassum from Kampani coastal areas

Phylum: Phaeophyta (= Ochrophyta)

Class: Phaeophyceae

Orders: Fucales Family: Sargassaceae

Genus: Sargassum C. Agardh 1920

Subgenus: Sargassum J. Agardh

Section: Binderiana (Grunow) Mattio et Payri Species:

(1) S. swartzii (Turner) C. Agardh

(2) S. cervicorne Greville

Section: Polycystae Mattio et Payri.

Species: (1) S. plagiophyllum C. Agardh (with and without stolons)

Sargassum swartzii (Turner) C. Agardh ${ }^{[19]} 1824$
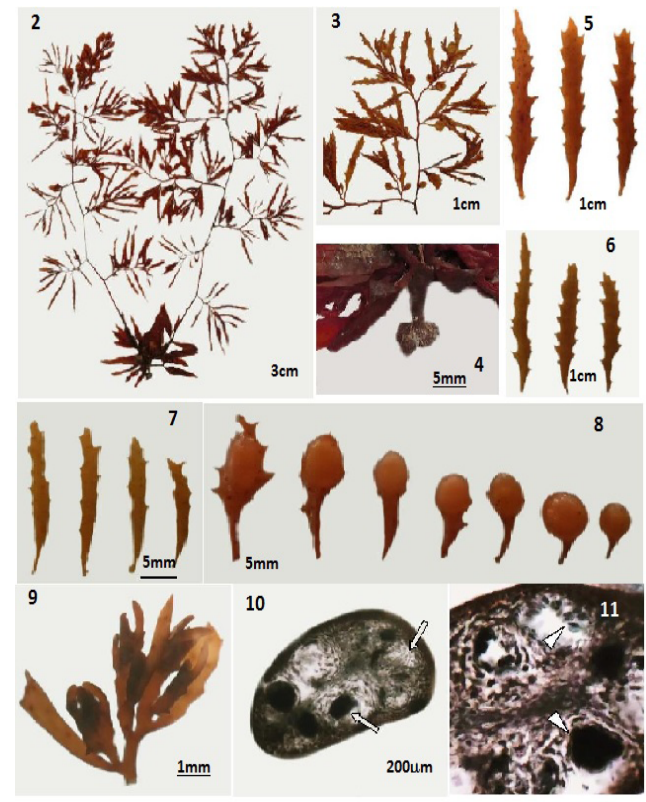

Figures 2-11: Sargassum swartzii (Turner) C. Agardh from the Kampani coastal areas: 2) Habitat of plant; 3) Apical part; 4) Holdfast; 5) Leaves of lower part; 6) Leaves of middle part; 7) Leaves of upper part; 8) Various shapes of vesicles; 9) Androgynous receptacle; 10) Cross-section of androgynous receptacle with antheridia and oogonia; 11) Antheridia and oogonia within the separate conceptacle (arrow heads). ${ }^{[16,19-36]}$

Type locality- 'Indian Ocean'[37](Silva, Basson and Moe 1996: 693).

Description: Vegetative features Plants attach by means of discoidal or conical holdfast. The holdfast is usually $2.0 \mathrm{~mm}$ thick and $4.0 \mathrm{~mm}$ in diameter; The primary stem is terete, up to 5.0 $\mathrm{mm}$ long and 1.0-2.0 $\mathrm{mm}$ in diameter usually without branching; Two to four main branches on the middle parts of the stem are 
flattened at the base to terete from middle part to upper portion, smooth, $15-20 \mathrm{~cm}$ in length and $1.0-1.5 \mathrm{~mm}$ in width without ridges and spinous processes; Leaves of main branches are simple, linear to linear-lanceolate in shape, $0.5-1.5 \mathrm{~cm}$ apart with a phyllotaxis of $1 / 3$ in spiral or alternate order, thick, shortly stipitate with asymmetrical bases, midribs percurrent and acute to obtuse apices, $3.0-3.5 \mathrm{~cm}$ in length and $3.0-4.0 \mathrm{~mm}$ in width and slightly wavy or not. The margins of the leaves are sharply serrate.

Cryptostomata are small, $100-150 \mu \mathrm{m}$ in diameter and scattered or aligned on each side of the midribs in one to several rows and spinous processes are absent on either sides of the stipe; Vesicles of secondary branches are large, mostly subspherical to ellipsoidal in shape, 7.0-17.0 mm in length and $3.0-5.0 \mathrm{~mm}$ in diameter, with lateral appendages and mucronate to rounded apices, sometimes foliar. The stipe of these vesicles are flattened in the lower part and compressed in the upper part generally slightly curved upwards with $1 / 2$ or $1 / 3$ length of vesicles; Reproductive features: The plant is monoecious. Receptacle branches are racemosely to cymosely arranged, long, slightly flattened with a few spines on apical part, irregularly forked, $2.0-4.0 \mathrm{~mm}$ in length and $1.0-1.5 \mathrm{~mm}$ in diameter with tapering or obtuse apex and mostly formed in the axils of leaves and vesicles of tertiary branches with a short sterile stipe. Receptacle is androgynous (Figures 9-10).

Specimens Examined in the Study Areas- Tanintharyi Coastal Region.- Southern Kampani (Hsu Mon Oo, 26.i.2013; MMB 11962-11963, Drift; Myo Min Tun ${ }^{[36]} 7 . i .2012$; MMB 1146311467); Thabawseik (Myo Min Tun, 10.i.2013; MMB 11113437).

Other specimens examined- Tanintharyi Coastal RegionMaungmagun (Aung Myint, 25.xii.1971; MMB 02203); Ayeyarwady Delta and Gulf of Mottama Coastal Region- No data; Rakhine Coastal Region.- Gwa Aw (Soe-Htun, 13.iv.1983; MMB 02860); Mhaw Chye (Soe- Htun, 17.iv.1980; MMB 02665; SoeHtun, 25.v.1980; MMB 02667); Maung Shwe Lay Gyaing (SoeHtun, 15.iv.1980; MMB 02663); Kyaukme Taung (Soe-Htun, 13.iii.1983; MMB 02858); Kyauk Phone Gyi Mhaw (Phyo Zaya, 5.iv.2004; MMB 04650); Lonetha (Soe- Htun, 26.i.1983; MMB 02844); Mazin (Soe- Htun, 31.i.1983; MMB 02852); AhLe-Than-Kyaw (Aung Myint, 25.iv.1970; MMB 02117);

Myanmar Distribution: Tanintharyi Coastal Region.- Kampani, Thabawseik (Mwe Taung), Maungmagan ${ }^{[38-40]}$; Ayeyarwady Delta and Gulf of Mottama Coastal Region.- No data; Rakhine Coastal Region.- Gwa Aw, Mhaw Chye, Maung Shwe Lay Gyaing, Kyaukme Taung, Kyauk Phone Gyi Mhaw, Lonetha, Mazin, Ah-Le-Than-Kyaw ${ }^{[38-40]}$.

World Distribution: Africa.- Kenya ${ }^{[37]}$; Indian Ocean Islands.Andaman Islands ${ }^{[37]}$, Indian Ocean[31], Nicobar Islands ${ }^{[37]}$; South-west Asia.- Bahrain, India, Iran, Pakistan, Persian Gulf, Sri Lanka ${ }^{[37]}$; Asia.- China (Tseng 1984), Hong Kong ${ }^{[41,32,33]}$, Ja$\operatorname{pan}^{[1]}$, Korea ${ }^{[1]}$, Taiwan ${ }^{[30]}$; South-east Asia.- Indonesia ${ }^{[1,37]}$, Malaysia $^{[43]}$, Singapore ${ }^{[37,2]}$, Myanmar $^{[42]}$ (This study), Thailand ${ }^{[34,43]}$, Vietnam $^{[28,1]}$ (Dai 2007); Australia and New Zealand.- Papua New Guinea(Mattio et al. 2009), Queensland ${ }^{[31]}$ (Mattio et al 2009); Pacific Islands.- New Caledonia ${ }^{[2]}$ (Mattio et al. 2009) .
Potential Utilization: Sargassum swartzii (Turner) C. Agardh is used as drugs ${ }^{[1]]}$, human foods, fodder, fish meal, manure and alginates ${ }^{[22,39,40]}$. It contains $17.23 \%$ of sodium alginate ${ }^{[44]}$. Sargassum cervicorne Greville 1849

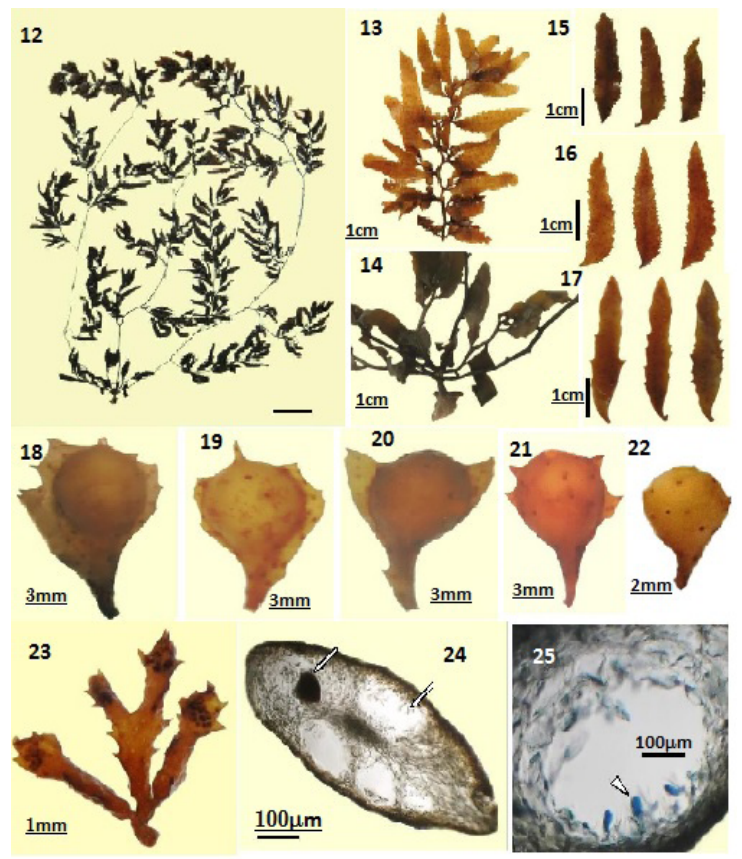

Figures 12-25: Sargassum cervicorne Greville from Kampani coastal areas: 12) Habitat of plant; 13) Apical part; 14) Holdfast; 15) Leaves of lower part (scale bar $=1.5 \mathrm{~cm}) ; 16)$ Leaves of middle part (scale bar = $1.5 \mathrm{~cm}) ; 17$ ) Leaves of upper part (scale bar $=0.5 \mathrm{~mm}$ ); 18-22) Various shapes of vesicles; 23) Androgynous receptacle; 24) Cross-section of androgynous receptacle with antheridia and oogonia (arrows); 25) Antheridia attach on conceptacle wall (arrow head). ${ }^{[16,26,32,33,35,45]}$

\section{Type Locality- India ${ }^{[2]}$.}

Description- Vegetative features: Plants attach by means of discoidal holdfast. The holdfast is usually $2.0-5.0 \mathrm{~mm}$ thick and $1.0-1.5 \mathrm{~mm}$ in diameter; The primary stem is terete, up to 5.0 $\mathrm{mm}$ long and 1.0-2.0 $\mathrm{mm}$ in diameter usually without branching; Two to four main branches on the middle parts of the stem are flattened at the base to terete from middle part to upper portion, smooth, $25-55 \mathrm{~cm}$ in length and $1.0-2.0 \mathrm{~cm}$ in width without ridges and spinous processes; Leaves of main branches are simple, lanceolate to linear-lanceolate in shape, 0.5-1.5 $\mathrm{cm}$ apart with a phyllotaxis of $1 / 3$ in spiral or alternate order, thick, shortly stipitate with asymmetrical bases, midribs percurrent and acute to obtuse apices, $1.0-5.0 \mathrm{~cm}$ in length and 0.5 $1.0 \mathrm{~cm}$ in width and slightly wavy or not. The margins of the leaves are sharply serrate to dentate. Cryptostomata are small, $100-150 \mu \mathrm{m}$ in diameter and scattered or aligned on each side of the midribs in one to several rows and spinous processes are absent on either sides of the stipe; Vesicles of secondary branches are large, mostly subspherical to ellipsoidal in shape, 2-6 mm in length and $0.5-2.5 \mathrm{~mm}$ in diameter, with or without lateral appendages and mucronate to rounded apices, or sometimes foliar. The stipe of these vesicles are terete in the lower part and compressed in the upper part generally slightly curved upwards with $1 / 2$ or $1 / 3$ length of vesicles; Reproductive features: The plant is monoecious. Receptacle branches are racemosely to cymosely arranged, long, flattened, twisted with spines on apical 
part, irregularly forked, $4.0-8.0 \mathrm{~mm}$ in length and $1.5-2.0 \mathrm{~mm}$ in diameter with tapering or obtuse apex and mostly formed in the axils of leaves and vesicles of tertiary branches with a short sterile stipe. Receptacle is androgynous and acanthocarpicae, or pseudozygocarpic (Figures 23-24).

Specimens Examined in the Study Areas: Tanintharyi Coastal Region- Thabawseik (Hsu Mon Oo, 6.xii.2012; MMB 11953, Drift; 26.i.2013; MMB 11954-11956, Drift); Southern Kampani (Myo Min Htike, 26.iii.2013; MMB 13030, Drift; Lin Lin Tun, 26.iii.2013; MMB 13031, Drift).

Other Specimens Examined: Co Co Island ${ }^{[16]}$ (Kyi Win, 14.i.1977; MMB 02508).

Myanmar Distribution: Tanintharyi Coastal Region.- Kampani, Thabawseik (Mwe Taung), Maungmagan ${ }^{[16,39,40]}$; Ayeyarwady Delta and Gulf of Mottama Coastal Region.- No Data; Rakhine Coastal Region.- Co Co Island ${ }^{[16]}$.

World Distribution: India ${ }^{[37]}$ (Sahoo et al. 2001), Pakistan, Sri Lanka $^{[37]}$; Asia: China ${ }^{[32,33]}$, Japan; South-east Asia: Indonesia ${ }^{[37]}$ , Singapore ${ }^{[37,2]}$.

Potential Utilization: Sargassum cervicorne Greville is used as drugs ${ }^{[11]}$, human food, fodder, fish meal, manure and alginates $^{[42,39,40]}$.

\section{Sargassum plagiophyllum C. Agardh ${ }^{[19]} 1824$}

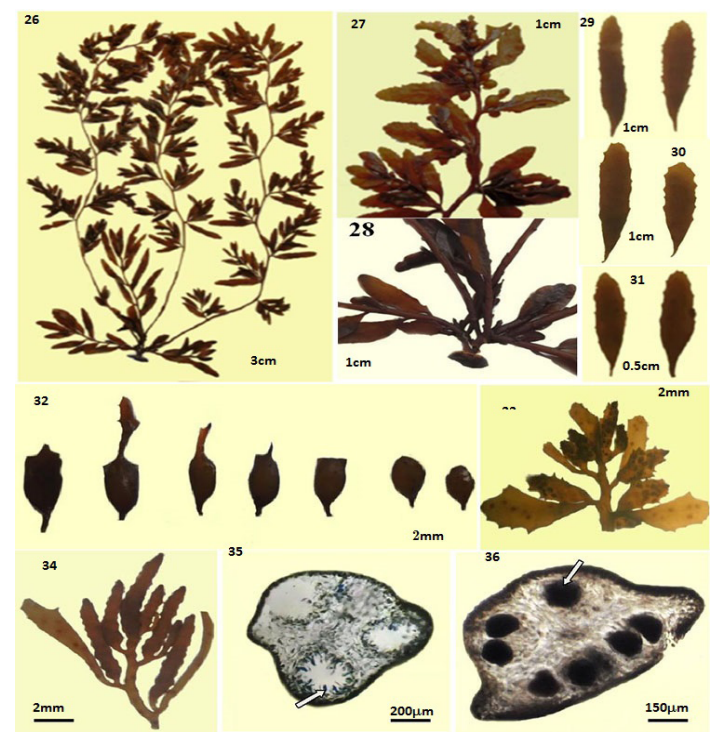

Figures 26-36: Sargassum plagiophyllum C. Agardh from Kampani coastal areas: 26) Habitat of plant; 27) Apical part; 28) Holdfast; 29) Leaves of basal part; 30) Leaves of middle part; 31) Leaves of apical part; 32) Various shapes of vesicles; 33) Female receptacle; 34) Male receptacle; 35) Cross-section of male receptacle with antheridia (arrow); 36) Cross- section of female receptacle with oogonia (arrow). $[17,19,20,22,23,25,26,30,36,46-49]$

Type Locality- 'In mari Indico' ${ }^{[37]}$ (Silva, Basson and Moe 1996: 693).

Description- Vegetative Features: Plants attach by means of discoidal holdfast. The holdfast is usually 2-5 $\mathrm{mm}$ thick and 5-7 $\mathrm{mm}$ in diameter; The primary stem is terete, $3-10 \mathrm{~mm}$ long and 1.5-2.0 $\mathrm{mm}$ in diameter usually without branching; Two to four main branches on the middle parts of the stem are terete, smooth, $10-35 \mathrm{~cm}$ in length and 1-2 mm in width without ridges and spinous processes; Leaves of main branches are simple, oblong to linear-lanceolate in shape, $0.5-1.5 \mathrm{~cm}$ apart with a phyllotaxis of $1 / 3$ in spiral order, somewhat thick or thin, shortly stipitate with asymmetrical bases, midribs percurrenct to disappear near at the apex and obtuse apices, $1-4 \mathrm{~cm}$ in length and $0.3-0.7 \mathrm{~cm}$ in width and not wavy. The margins of the leaves are entire to slightly or irregularly serrate margins. Cryptostomata are small, $100-150 \mu \mathrm{m}$ in diameter and scattered or aligned on each side of the midribs in one to several rows and spinous processes are absent on either sides of the stipe; sometimes foliar; Vesicles of secondary branches are mostly ellipsoidal in shape, 2-6 $\mathrm{mm}$ in length and $0.5-2.5 \mathrm{~mm}$ in diameter, without lateral appendages and mucronate to rounded apices, sometimes foliar. The stipes of these vesicles are generally straight with $1 / 2$ or $1 / 3$ length of vesicles. The stipes of these vesicles are generally straight with $1 / 2$ or $1 / 3$ length of vesicles; Reproductive features: The plant is dioecious. Male receptacle branches are racemosely arranged, long, terete, smooth or verrucose, irregularly forked, $5-15 \mathrm{~mm}$ in length and 1-1.5 mm in diameter with tapering or obtuse apex and mostly formed in the axils of leaves and vesicles of tertiary branches with a

Vesicles- Vesicles of secondary branches are mostly ellipsoidal in shape, 2-6 mm in length and 0.5-2.5 $\mathrm{mm}$ in diameter, without lateral appendages and mucronate to rounded apices, short sterile stipe. Male receptacle is pseudozygocarpic (Figures 3435); Female receptacle branches are racemosely arranged, compressed or triquetrous, smooth at the base and spiny at the lower middle at upper parts, irregularly forked, 3-5 $\mathrm{mm}$ in length and $1-1.5 \mathrm{~mm}$ in width and mostly formed in the axils of leaves and vesicles of tertiary branches with a short sterile stipe. Female receptacle is pseudozygocarpic (Figures.33,36).

Specimens Examined in the Study Areas-Tanintharyi Coastal Region- Southern Kampani (Hsu Mon Oo, 6.xii.2012; MMB 11939-11949; Myo Min Tun ${ }^{[36]}$ 30.ix.2012; MMB 11210,11214,11216; Htet Ko Ko, 26.iii.2013; MMB 13001; Thet Paing Soe, 26.iii.2013; MMB 13002; Aung Myo Win, 26.iii.2013; MMB 13003; Chuu Zin Thu, 26.iii.2013; MMB 13004; Lin Thet San, 26.iii.2013; MMB 13005; Aung Ye Thu, 26.iii.2013; MMB 13006; Thura Hein, 26.iii.2013; MMB 13007; Htet Nay Lin, 26.iii.2013; MMB 13008; San Naing Phyo, 26.iii.2013; MMB 13009; Soe Htet Naing Lwin, 26.iii.2013; MMB 13010; Htet Myat Maw, 26.iii.2013; MMB 13011; Aye Chan Maung, 26.iii.2013; MMB 13012; Kyaw Thiha, 26.iii.2013; MMB 13013; Win Warso Aung, 26.iii.2013; MMB 13014; Hein Min Paing, 26.iii.2013; MMB 13015; Kyaw Zin Ko, 26.iii.2013; MMB 13016; Aung Myo Thu, 26.iii.2013; MMB 13017; Zin Moh Moh Tun, 26.iii.2013; MMB 13018; Chit Ar Poe, 26.iii.2013; MMB 13019; Min Janes Bond, 26.iii.2013; MMB 13020; Nyan Moe Naing, 26.iii.2013; MMB 13021; May Poe Oo, 26.iii.2013; MMB 13022; Min Aung, 26.iii.2013; MMB 13023; Pyae Phyo Kyaw, 26.iii.2013; MMB 13024; Aung Mon, 26.iii.2013; MMB 13025; Aung Ko Latt, 26.iii.2013; MMB 13026; Su Pyae Tun, 26.iii.2013; MMB 13027; Min Than Htike Oo, 26.iii.2013; MMB 13028; Yamong Phoo, 26.iii.2013; MMB 13029); Thabawseik (Hsu Mon Oo, 26.x.2012; MMB 1195811961, 6.xii.2012; MMB 11922-11938, 27.i.2013; MMB 11950; 
Myo Min Tun, 15.ii.2013; MMB 111138).

Other Specimens Examined- Tanintharyi Coastal RegionMaungmagun $^{[16]}$; Thabawseik (Mwe Taung) (4 ${ }^{\text {th }}$ year students, 15.iv.1980; MMB 02656; Myint Aung, 23.xii.1980; MMB 02657); Ayeyarwady Coastal Region- No data; Rakhine Coastal Region- Mawtin Point (Ne Aung Win, 2.xii.1976; MMB 02453; Murial Dwe Hla, 7.xii.1976; MMB 2457); Zeegyaing (Aung Myint, 5.i.1974; MMB 02342; Ohmar Kyi, 4.xii.1976; MMB 02454; Mu Mu Aye and Ma Myint Than, 17.ii.1980; MMB 02655); Cape Nagraris (Aung Myint, 22.ii.1978; MMB 02552); Gwa Aw (Aye Pyo, 23.i.1971; MMB 02201); Maung Shwe Lay Seaweed culture line (Soe Lwin, 15.vii.1983; MMB 02869).

Myanmar Distribution: Tanintharyi Coastal Region.- Kampani, Thabawseik (Mwe Taung), Maungmagan, San Hlann ${ }^{[38-40]}$; Ayeyarwady Delta and Gulf of Mottama Coastal Region.- No Data; Rakhine Coastal Region.- Mawtin Point, Zeegyaing, Cape Nagraris, Gwa Aw, ), Maung Shwe Lay Gyaing ${ }^{[38-40]}$.

World Distribution: South-west Asia.- India ${ }^{[37]}$, Sri Lanka ${ }^{[37]}$; Asia.-China $^{[49]}$, Taiwan ${ }^{[30]}$; South-east Asia.- Myanmar ${ }^{[42]}$, Thailand $^{[50]}$, Malaysia ${ }^{[43]}$, Indonesia ${ }^{[37]}$, Singapore ${ }^{[37]}$, Philippines ${ }^{[5]]}$; Australia and New Zealand.-Australia ${ }^{[49]}$, Queensland (Lewis 1985); Pacific Ocean: Fedarated States of Micronesia, Northern Gulf of California ${ }^{[2]}$.

Potential utilization- Sargassum plagiophyllum C. Agardh is used as drugs ${ }^{[11]}$, human food, fodder, fish meal, manure and alginates ${ }^{[39,40,42]}$. It contains $15-19 \%$ of sodium alginate ${ }^{[44]}$.

Sargassum plagiophyllum C. Agardh sensu Mattio et Payri (=S. stolonifolium Phang et Yoshida ${ }^{[55]}$ 1997)

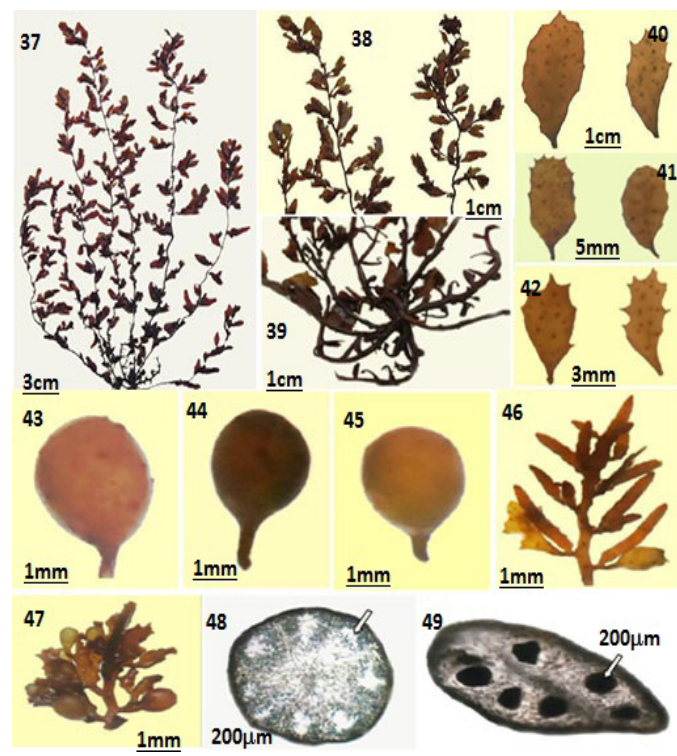

Figures 37-49: Sargassum plagiophyllum C. Agardh (= S. stolonifolium Phang et Yoshida) from Kampani coastal areas: A) Habitat of plant; B) Apical part; C) Holdfast; D) Leaves of basal part; E) Leaves of middle part; F) Leaves of apical part; G-I) Various shapes of vesicles; J) Male receptacle; K) Female receptacle; L) Cross-section of male receptacle with antheridia (arrow); M) Cross-section of female receptacle with oogonia (arrow). ${ }^{[2,17,35,36,39,52-54]}$

Type locality- Penang, Malaysia ${ }^{[52]}$
Description- Vegetative Features: Plants attach by means of discoidal holdfast. The holdfast is usually 1-3 mm thick and 2-5 $\mathrm{mm}$ in diameter; The primary stem is terete, $3.0-12.0 \mathrm{~mm}$ long and $1.5-2.0 \mathrm{~mm}$ in diameter usually without branching; Primodial branches located at the upper part of the primary stem are modified into stolons, compressed at the base and terete from lower middle to upper parts, $3.0-12 \mathrm{~cm}$ in length and $2-3 \mathrm{~mm}$ in width without ridges and spinous processes; Leaves of main branches are simple, oblong to ovoid in shape, $0.5-1.5 \mathrm{~cm}$ apart with a phyllotaxis of $1 / 3$ in spiral order, somewhat thick or thin, shortly stipitate with asymmetrical bases, midribs petcurrenct to disappear near at the apex and generally obtuse to rounded apices, $1-3 \mathrm{~cm}$ in length and $0.4-1.0 \mathrm{~cm}$ in width and slightly wavy. The margins of the leaves are entire to slightly or irregularly serrate margins. Cryptostomata are large, $100-250 \mu \mathrm{m}$ in diameter and scattered or aligned on each side of the midribs in one to several rows and spinous processes are absent or present on either sides of the stipe; Vesicles of secondary branches are mostly spherical to ellipsoidal in shape, 1.5-4 mm in length and 1.0-3.0 $\mathrm{mm}$ in diameter, without lateral appendages and mucronate to rounded apices, sometimes foliar. The stipe of these vesicles are slightly compressed to terete and slightly curved with $1 / 2$ or $1 / 3$ length of vesicles;

Reproductive Features: The plant is dioecious. Male receptacle branches are racemosely arranged, long, terete, smooth or verrucose, irregularly forked, $6.0-8.0 \mathrm{~mm}$ in length and 0.5 $1.0 \mathrm{~mm}$ in diameter with tapering or obtuse apex and mostly formed in the axils of leaves and vesicles of tertiary branches with a short sterile stipe. Male receptacle is pseudozygocarpic (Figures.46,48); Female receptacle branches are racemosely or cymosely arranged, compressed or triquetrous, smooth at the base and spiny at the lower middle at upper parts, irregularly forked, $2.5-4.0 \mathrm{~mm}$ in length and $0.5-1.0 \mathrm{~mm}$ in width and mostly formed in the axils of leaves and vesicles of tertiary branches with a short sterile stipe. Female receptacle is holozygocarpic (Figures 47,49).

Specimens Examined in the Study Areas- Tanintharyi Coastal Region- Thabawseik (Hsu Mon Oo, 6.xii.2012; MMB 1190711919, 11926; 26.i.2013; MMB 11951-11952; Myo Min Tun, 15.ii.2013; MMB 111139-41).

Other Specimens Examined- Tanintharyi Coastal Region- St. Luke I(Soe- Htun, 20.xii.1997; MMB 09937-09939); Ayeyarwady Coastal Region- No data; Rakhine Coastal Region- Zeegyaing (Mu Mu Aye and Ma Myint Than, 17.ii.1980; MMB 02653; Aye Thwin, 15.i.1984; MMB 02906); Makyeengu (Gwa Aw) (Soe Lwin, 13.iv.1983; MMB 02809); Yahaingkutoe (Aye Pyo, 8.iv.1971; MMB 02250); Maungshwelay Seaweed culture line (Soe Lwin, 10.v.1984; MMB 02957); Sin Gaung (Soe Naing, 18.iv.1981; MMB 2749); Kyauk La Yaine Gyaing (Mya Kyawk Wai, 14.xii.2008; MMB 11093, 10094-10097, 10241); Kyaukoomaw (Aung Myint, 7.iv.1974; MMB 02399); U Ba Saw's Pagoda(Aung Myint, 10.iv.1974; MMB 2400).

Myanmar Distribution: Tanintharyi Coastal Region- St. Luke I., Kampani, Thabawseik (Mwe Taung), Maungmagann ${ }^{[38-40]}$; Ayeyarwady Delta and Gulf of Mottama Region- No Data; Rakhine Coastal Region- Mawtin Point, Zeegyaing, Shwe Ya Gyaing, 
Makyeengu (Gaw Aw), Yahaingkutoe, Hlyaw Gaung Taung, Maw Shwe Gyaing, Maung Shwe Lay Gyaing, Kyauk La Yaine Gyaing,Lonetha, Ngapali, Mazin, Sing Gaung, Kyaukoomaw, U Ba Saw's Pagoda ${ }^{[38-40]}$.

World Distribution: South-east Asia.- Myanmar ${ }^{[42]}$, Malay$\operatorname{sia}^{[53,34,35]}$ (Stiger et al.2004), Thailand ${ }^{[34,54,50,2]}$.

Potential Utilization: Sargassum plagiophyllum C. Agardh sensu Mattio et Payri (= S. stolonifolium Phang et Yoshida) is used as drugs ${ }^{[11]}$, human food, fodder, fish meal, manure and alginates $^{[42,39,40]}$. It contains $15-19 \%$ of sodium alginate ${ }^{[44]}$.

\section{Discussion}

In the present study, the three species of Sargassum subgenus Sargassum, namely Sargassum swartzii (Turner) C. Agardh, S. cervicorne Greville and S. plagiophyllum C. Agardh (with or without stolons) have been recorded from Kampani coastal areas. A comparison of the taxonomically reliable characteristics of vegetative and reproductive features for each species is shown in Table 1.

Table 1: A comparison of the morphological features in three species of Sargassum in Kampani coastal areas.

\begin{tabular}{|c|c|c|c|c|c|}
\hline \multirow{3}{*}{$\begin{array}{l}\text { Sr. } \\
\text { No }\end{array}$} & \multirow{3}{*}{$\begin{array}{c}\text { Charac- } \\
\text { ters }\end{array}$} & \multicolumn{4}{|c|}{ Species } \\
\hline & & \multirow[b]{2}{*}{$\begin{array}{c}S . \\
\text { swartzii }\end{array}$} & \multirow[b]{2}{*}{$\begin{array}{l}\text { S. cervi- } \\
\text { corne }\end{array}$} & \multicolumn{2}{|c|}{ S. plagiophyllum } \\
\hline & & & & $\begin{array}{l}\text { without sto- } \\
\text { lons S. pla- } \\
\text { giophyllum }\end{array}$ & $\begin{array}{l}\text { with stolons } \\
\text { S. stolonifo- } \\
\text { lium }\end{array}$ \\
\hline 1. & $\begin{array}{l}\text { Hold - } \\
\text { fast }\end{array}$ & Discoid & Discoid & Discoid & Discoid \\
\hline 2. & Stem & Terete & Terete & Terete & Terete \\
\hline 3. & $\begin{array}{l}\text { P r i - } \\
\text { m a r y } \\
\text { branch- } \\
\text { es }\end{array}$ & $\begin{array}{l}\text { Compressed, } \\
\text { smooth }\end{array}$ & $\begin{array}{l}\text { Flattened } \\
\text { into com- } \\
\text { pressed, } \\
\text { smooth }\end{array}$ & $\begin{array}{l}\text { Terete } \\
\text { smooth }\end{array}$ & $\begin{array}{l}\text { Terete, } \\
\text { smooth, } \\
\text { twisted, } \\
\text { transformed } \\
\text { into srolons }\end{array}$ \\
\hline 4. & $\begin{array}{l}\text { S e c - } \\
\text { ondary } \\
\text { branch- } \\
\text { es }\end{array}$ & $\begin{array}{l}\text { Slightly } \\
\text { compressed } \\
\text { to terete, } \\
\text { smooth }\end{array}$ & $\begin{array}{l}\text { Slightly } \\
\text { compressed } \\
\text { to terete, } \\
\text { smooth }\end{array}$ & $\begin{array}{l}\text { Terete, } \\
\text { smooth }\end{array}$ & $\begin{array}{l}\text { Terete, } \\
\text { smooth }\end{array}$ \\
\hline 5. & $\begin{array}{l}\text { Leaves: } \\
\text { (i) Pri- } \\
\mathrm{m} \text { a r y } \\
\text { leaves }\end{array}$ & $\begin{array}{l}\text { Elongated } \\
\text { lanceolate } \\
\text { to linear } \\
\text { lance olate, } \\
\text { asymmetrical } \\
\text { base, acute } \\
\text { or some- } \\
\text { times ob- } \\
\text { tuse apices, } \\
\text { detate mar- } \\
\text { gins, midribs } \\
\text { percurrent or } \\
\text { evanescent, } \\
\text { cryptostoma- } \\
\text { ta less, one } \\
\text { tow or two } \\
\text { rows on both } \\
\text { sides of the } \\
\text { midribs }\end{array}$ & $\begin{array}{l}\text { Lanceolad- } \\
\text { te to linear, } \\
\text { a s y m met- } \\
\text { rical bases, } \\
\text { r o u n d e d } \\
\text { to slightly } \\
\text { acute apiced, } \\
\text { sharply ser- } \\
\text { rate marigns, } \\
\text { percurrent } \\
\text { midribs, } \\
\text { cryptosto- } \\
\text { mata ran- } \\
\text { domly dis- } \\
\text { tributed on } \\
\text { both sides of } \\
\text { the midribs. }\end{array}$ & $\begin{array}{l}\text { Oblong to lin- } \\
\text { earlanceolate, } \\
\text { asymmetrical } \\
\text { base, obtuse } \\
\text { to rounded } \\
\text { apices, entire } \\
\text { to slightly } \\
\text { or irregu- } \\
\text { larly serrate } \\
\text { m a g i n s, } \\
\text { midribs per- } \\
\text { current or dis- } \\
\text { appear near } \\
\text { the apices, } \\
\text { cryptosto- } \\
\text { mata small, } \\
\text { scattered or } \\
\text { aligned on } \\
\text { each side of } \\
\text { the midribs. }\end{array}$ & $\begin{array}{l}\text { Oblong } \\
\text { to ovoid, } \\
\text { a sy m m et- } \\
\text { rical base, } \\
\text { acute to } \\
\text { rounded api- } \\
\text { ces, entire to } \\
\text { slightly or } \\
\text { irregularly } \\
\text { serrate mar- } \\
\text { gins, percur- } \\
\text { rent midribs, } \\
\text { cryptosto- } \\
\text { mata large, } \\
\text { scatted on } \\
\text { both sides of } \\
\text { the midribs }\end{array}$ \\
\hline
\end{tabular}

\begin{tabular}{|c|c|c|c|c|c|}
\hline & $\begin{array}{l}\text { (ii) Sec- } \\
\text { ondary } \\
\text { leaves }\end{array}$ & $\begin{array}{l}\text { Linear-lan- } \\
\text { c e o } 1 \text { a t e, } \\
\text { asymmetrical } \\
\text { base, acute } \\
\text { apices, den- } \\
\text { tate margins, } \\
\text { midribs per- } \\
\text { current cryp- } \\
\text { tostomata in } \\
\text { one to two } \\
\text { rows }\end{array}$ & $\begin{array}{l}\text { Lanceolate } \\
\text { to linear, } \\
\text { a sy m m et- } \\
\text { rical base, } \\
\text { cacute to } \\
\text { rounded api- } \\
\text { ces serrate } \\
\text { to slightly } \\
\text { serrate mar- } \\
\text { gins, midribs } \\
\text { percurrent, } \\
\text { cryptosto- } \\
\text { mata ran- } \\
\text { domly dis- } \\
\text { tributed on } \\
\text { both sides of } \\
\text { the midribs. }\end{array}$ & $\begin{array}{l}\text { Lanceolate } \\
\text { to linear, } \\
\text { asymmetrical } \\
\text { base, acute to } \\
\text { rounded api- } \\
\text { ces, slightly } \\
\text { serrate mar- } \\
\text { gins, midribs } \\
\text { percurrent } \\
\text { or disappear } \\
\text { near the api- } \\
\text { ces, cryp- } \\
\text { to s t o m a t a } \\
\text { scattered on } \\
\text { both sides of } \\
\text { the midribs }\end{array}$ & $\begin{array}{l}\text { Elliptical, } \\
\text { as ym met- } \\
\text { rical base, } \\
\text { acute to } \\
\text { rounded, } \\
\text { apices, } \\
\text { slightly } \\
\text { serrate to } \\
\text { serrate mar- } \\
\text { gins, percur- } \\
\text { rent midribs, } \\
\text { cryptosto- } \\
\text { mata large, } \\
\text { rando m ly } \\
\text { distribut- } \\
\text { ed over the } \\
\text { leaves sur- } \\
\text { face }\end{array}$ \\
\hline 6. & $\begin{array}{l}\text { Ve s i - } \\
\text { cles }\end{array}$ & $\begin{array}{l}\text { Ellipsoidal } \\
\text { to spherical, } \\
\text { apex point- } \\
\text { ed or with a } \\
\text { short leafy } \\
\text { crown }\end{array}$ & $\begin{array}{l}\text { Spherical, } \\
\text { rounded api- } \\
\text { ces }\end{array}$ & $\begin{array}{l}\text { Ellipsoidal, } \\
\text { mucronate to } \\
\text { rounded api- } \\
\text { ces }\end{array}$ & $\begin{array}{l}\text { Spherical to } \\
\text { ellipsoidal, } \\
\text { mucronate } \\
\text { to rounded } \\
\text { apices, }\end{array}$ \\
\hline 7. & $\begin{array}{l}\text { Recep- } \\
\text { tacles: } \\
\text { Monoe- } \\
\text { cious }\end{array}$ & $\begin{array}{l}\text { Slightly ter- } \\
\text { ete, small } \\
\text { spines at the } \\
\text { apices and } \\
\text { margins. }\end{array}$ & $\begin{array}{l}\text { Flattened, } \\
\text { twisted with } \\
\text { spines, acan- } \\
\text { thocarpic }\end{array}$ & & \\
\hline & $\begin{array}{l}\text { (i) D i - } \\
\text { oecious } \\
\text { (male) }\end{array}$ & - & - & $\begin{array}{l}\text { Long terete, } \\
\text { simple or } \\
\text { irregularly } \\
\text { fork, pseudo- } \\
\text { zygocarpic }\end{array}$ & $\begin{array}{l}\text { Long, terete } \\
\text { with wavy } \\
\text { outlines and } \\
\text { generally bi- } \\
\text { furcate tips, } \\
\text { pseudozygo- } \\
\text { carpic. }\end{array}$ \\
\hline & $\begin{array}{l}\text { (ii) Di- } \\
\text { oecious } \\
(\mathrm{f} e- \\
\text { male) }\end{array}$ & - & - & $\begin{array}{l}\text { Slightly com- } \\
\text { pressed to tri- } \\
\text { quetrous, } \\
\text { sometimes } \\
\text { bearing } \\
\text { spines at } \\
\text { the surface, } \\
\text { pseudozygo- } \\
\text { carpic or ho- } \\
\text { lozygocarpic }\end{array}$ & $\begin{array}{l}\text { Short, com- } \\
\text { pressed with } \\
\text { wavy out- } \\
\text { lines and bi- } \\
\text { furcate tips, } \\
\text { pseudozygo- } \\
\text { carpic. }\end{array}$ \\
\hline
\end{tabular}

Soe-Htun ${ }^{[17]}$ firstly described the developmental process of vegetative and reproductive features in Sargassum spp. including the stoloniferous species as Sargassum herporhizum Setchell and Gardner with furcate cauline leaves under S. subgen. Sargassum.

Moreover, Soe-Htun and Yoshida ${ }^{[4]}$ also proposed the developmental process of vegetative and reproductive features in S. cristaefolium C. Agardh. Likewise, Kilar et al ${ }^{[6,7]}$ again reported that the developmental process of Sargassum species with the modification of the previous report of Soe-Htun and Yoshida $^{[4]}$.

Tseng and $\mathrm{Lu}^{[32,33]}$ reported five main characteristics of Sargassum swartzii that are flattened and compressed primary branches, cymosely arranged receptacles, ellipsoidal vesicles with long pedicels, leaves lanceolate with percurrent midribs, softening and dropping off of some parts when dried specimens are soak in water, thus damaging the appearance of the specimens. Ajisaka ${ }^{[34]}$ also reported that $S$. swartzii (Turner) C. Agardh can be differentiated from S. binderi Sonder and S. oligocystum Montagne on the basis of its slender leaves and smaller vesicles 
with mucronate and closely clustered receptacles. However, Noiraksar and Ajisaka ${ }^{[55]}$ also reported Thai species of Sargassum swartzii (Turner) C. Agardh which shows some resemblance to $S$. binderi Sonder and S. oligocystum Montagne, but can be distinguished from those species by their linear-lanceolate leaves with shallow dentate to entire margins, small vesicles with terete stalks and entire margins and receptacles arranged in a cymose. By contrast, the present specimens is closely related to $S$. swartzii (Turner) C. Agardh from China ${ }^{[32,33]}$, Malaysia $^{[34]}$ and Thailand ${ }^{[55]}$ in having those characters. Moreover, the present specimens also resemble to those from Australia ${ }^{[31]}$ which have linear leaves, subspherical vesicles and terete receptacles. SoeHtun $^{[17]}$ described the Myanmar species of Sargassum swartzii (Turner) C. Agardh are dioecious but the present specimens are monoecious, antheridia and oogonia occur in separate conceptacles or sometimes in same conceptacles.

Durairatnam $^{[45]}$ reported $S$. cervicorne Greville with flattened branches, linear-lanceolate leaves equally attenuated at both ends, entire or rarely furnished with sharp teeth upwards and elliptical vesicles borne on dilated foliaceous petioles about the same length as the vesicles, among 13 species of Sargassum from Ceylon (Sri Lanka). He described receptacles were pedunculate more or less divided racemes compressed, irregular in shape and toothed and did not mention these as dioecious or monoecious. In this study, the receptacles of the plants are monoecious. In Myanmar, Kyaw Soe and Kyi Win ${ }^{[16]}$ firstly reported $S$. cervicorne Greville collected from Maungmagan. In general, the present specimens of $S$. cervicorne Greville are closely resembled to some characteristics such as the shapes and sizes of the leaves and vesicles of the Sri Lankan specimens ${ }^{[45]}$ and specimens of Maugmagan ${ }^{[16]}$.

Tseng and $\mathrm{Lu}^{[33]}$ studied the two subseries: the Swartziia and the Binderia of the series Binderiana under the section Acanthocarpicae in which the Swartzia group were consisting of 10 species: 8 species of these from China with each species of Hawaii and India. Among these, the Chinese species, S. cervicorne Greville is reduced to a variety of $S$. binderi in Grunow's $\operatorname{monograph}^{[23]}$. However, they recovered the species status of $S$. cervicorne Greville after going through hundreds of specimens which are grouped under the Swartzia. They described differences in the vesicles and receptacles in this species as compared to $S$. binderi Sonder and also reported that this species was related to $S$. dumosum Greville. However, Wong et al ${ }^{[35]}$ descried the characters of $S$. cervicorne Greville along with flattened branches, ellipsoidal vesicles with long leafy pedicels, glomerulate receptacles which are dilated in the upper part and lanceolate leaves with serrate to double serrate margin and obtuse apices. Specimens of $S$. cervicorne Greville in the present study are closely related to the species from Malaysia ${ }^{[35]}$ based on the characters as mentioned above.

Noiraksar and Ajisaka ${ }^{[55]}$ stated that Sargassum binderi Sonder and S. oligocystum overlap in many morphological characters, particularly when they are immature but $S$. oligocystum is dioecious. $S$. binderi was placed as the synonym of $S$. oligocystum Montagne by Womersely and Bailey. However, Tseng and $\mathrm{Lu}^{[33]}$ and Ajisaka et $a^{[53]}$. argued that facts and supported the original description of S. binderi Sonder by J.G. Agardh ${ }^{[20]}$, retaining as a separated species by itself. Recently, this species had also been synonymised as S. aquifolium (Turner) C. Agardh by Mattio et $a l^{[3]}$. based on morphological and molecular anal- ysis. The species of $S$. cervicorne Greville is closely related to $S$. binderi Sonder from China, Malaysia and Thailand ${ }^{[33,53,55]}$ due to some vegetative structures such as branches and leaves, but different in vesicles and receptacles. Nevertheless, the growth pattern in the development of furcate cauline leaf and dwarfs of main branch as well as different orders of branches, leaves, vesicles and receptacles of Sargassum section Binderiana belonging to the S. subgenus Sargassum from the study areas is closely resemble to that of Sargassum cristaefolium reported by Soe-Htun and Yoshida ${ }^{[4]}$ and Sargassum polyceratium described by Kilar and Hanisk ${ }^{[5]}$.

Recently, Soe-Htun et al ${ }^{[18]}$ presented the growth pattern in the development of simple cauline leaf, the primordial branches or the dwarf or determinate branches or stolons modified from dwarfs of main branch and secondary branches as well as different orders of branches, leaves, vesicles and receptacles. They observed that the dwarf or determinate main branches issued on the uppermost parts of the primary stem were normally transformed into stolons. In other words, these determinate branches gradually changed into indeterminate branches which in turn lengthened together with tip of each branch issued tending to surface of the substrates. At the same time, the midribs of leaves of the dwarf branches also enlarged, reducing and disappearing foliar structures on both sides and then changed into stout branchlets with hapteras attached to the substrates at the tips, transforming as stolons. Because of the dwarf branches which were very close to the substrates, it was normally transformed into stolons in mature plants of S. plagiophyllum C. Agardh (with stolons) but not in S. plagiophyllum C. Agardh (without stolons). They proposed the presence of simple cauline leaves and specific developmental sequences of dwarf branches or stolons, if present, should be assigned as the main taxonomic criteria of the Sargassum sect. Polycystae designated by Mattio et $a l^{[8]}$.

Recently, S. stolonifolium Phang et Yoshida characterized by the presence of stolons had also been synonymised as S. plagiophyllum C. Agardh in which the formation of stolons was entirely absent throughout the life span by Mattio et al ${ }^{[3]}$. based on morphological and molecular analysis. Soe-Htun ${ }^{[17]}$ had previously identified this stoloniferous species without murication on branches as $S$. herporhizum Setchell et Gardner by in accordance with the description and illustration given by Setchell and Gardner ${ }^{[56]}$ and Dawson ${ }^{[57]}$ (p. 249, pl.40, figs. 1-12) for $S$. herporhizum Setchell et Gardner collected from California. However, this species (as $S$. herporhizum Setchell et Gardner sensu Soe-Htun ${ }^{[17]}$ ) had been established as a new species, $S$. stolonifolium by Phang and Yoshida ${ }^{[52]}$ based on the specimens collected from Penang, Malaysia.

In the present study, there were two types of plants under the Sargassum sect. Polycystae designated by Mattio et al ${ }^{[8]}$ primordial branches or the dwarf or determinate branches which are transformed into stolons in adult plants; and 2) primordial branches or the dwarf or determinate branches which are not transformed into stolons in adult plants, as described by SoeHtun et $a l^{[18]}$. It was noted that, in the first type of stoloniferous species, dwarfs of main branch on primary stem as well as the secondary branches formed at the lower part of main branches were able to be transformed into stoloniferous branches in some plants found exposed to heavy wave action in the lower intertidal zones of the Southern Kampani coastal areas (Figures.50-52). 
The formation of newly propagated plantlets issued from the attached haptera of different orders branches in Sargassum plagiophyllum sensu Mattio et Payri $(=S$. stolonifolium $)$ collected from the lower intertidal zone was diagrammatically shown in Figure 53. By contrast, Phang and Yoshida ${ }^{[52]}$ had described the stolons of this species were derived from the cauline leaves and produced secondary holdfast (haptera) on contact with the substratum and then new plantlets were formed. On the other hand, in the latter type species, i.e. Sargassum plagiophyllum C. Agardh (without stolons) collected from Kampani coastal areas, the growth pattern in the development of dwarfs of main branch on primary stem and secondary branches as well as different orders of branches, leaves, vesicles and receptacles is closely similar to those of S. cristaefolium C. Agardh described by Soe-Htun and Yoshida ${ }^{[4]}$, except for the formation of simple cauline leaves.

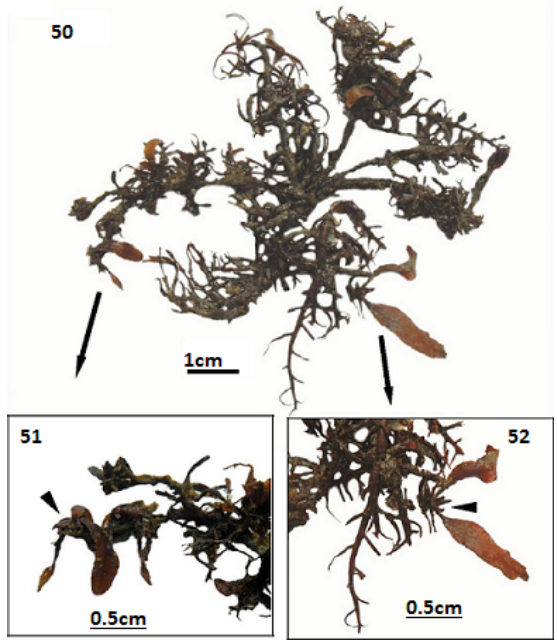

Figure 50-52: The formation of newly propagated plantlets from the attached haptera of Sargassum plagiophyllum sensu Mattio et Payri $(=S$. stolonifolium $)$ collected from the lower intertidal zone of Southern Kampani coastal areas: 51) Habit of plant showing stoloniferous branches with young plantlet; 52) The newly propagated plantlet (arrow head) issued from the haptera of stoloniferous branch which was transformed from the secondary branch; 53) The newly propagated plantlet (arrow head) issued from the haptera of stoloniferous branch which was transformed from the dwarf of main branch.

Moreover, Ajisaka and Lewmanomount ${ }^{[54]}$ reported two type of morphology in cauline leaves on the stem, (i) elliptical cauline leaves from the upper portions and (ii) cylindrical stolons from the lower portions. By contrast, in the present study, elliptical cauline leaves were observed at the lower portions and cylindrical stolons from the upper portions. In addition, Ajisaka and Lewmanomount ${ }^{[54]}$ reported that among other two species with stolons, S. polycystum C. Agardh and S. herporhizum Setchell et Gardner produces branched stolons from the stem into attaching branches, haptera to new plantlets. The present study on S. plagiophyllum C. Agardh (with stolons) generally agrees well with their observations on the presence of stolons on the stem and the new plantlets which were regenerated from the stolons (haptera) in Sargassum polycystum C. Agardh and S. herporhizum Setchell et Gardner. They did not mention the location of stolons, as compared with the present study which emphazised the location of stolon derived from the primodial branches (dwarf branches) as well as the secondary branches in S. plagiophyllum C. Agardh (with stolons).

In the present study, the stolons branches are twist- ing and forming net-work with each other in S. plagiophyllum C. Agardh (with stolons) growing in the lower intertidal zone due perhaps to heavy wave actions and other environmental factors (Figures.51-53). The findings on both species of $S$. plagiophyllum C. Agardh (with stolons) in heavily wave-exposed conditions and S. plagiophyllum C. Agardh (without stolons) in calm conditions in the present study sites also agreed with the observations of Ajisaka and Lewmanomount ${ }^{[54]}$ who reported that the formation of the stolons was not necessary for plants in stable environmental conditions on the calm coasts or when protected by rocks from strong waves but it might be necessary on wave-exposed coasts. Interestingly, Sargassum plagiophyllum sensu Mattio et Payri (= S. stolonifolium Phang et Yoshida) possess stolons formed from the modified dwarf main branches located at the top of the primary stem characterized by the formation of newly propagated plantlets from the tips of each and the secondary branches on the main branches, and is stoloniferous branch in wave-exposed lower intertidal zones. Sargassum plagiophyllum sensu Mattio et Payri (=S. stolonifolium Phang et Yoshida) which shows the formations of new plantlets can be utilized in mass cultivation of Sargassum by the method of vegetative propagation for the production of raw materials to produce the valuable product of alginates.

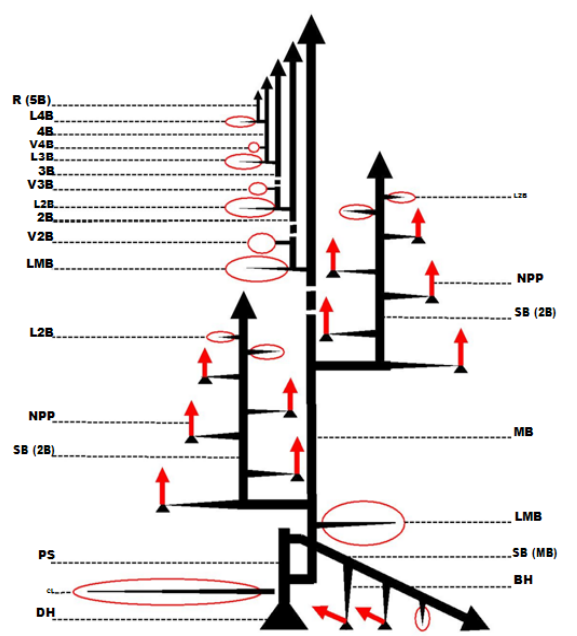

Figure 53: The schematic diagram of the development of newly propagated plantlets in Sargassum section Polycystae belonging to the S. subgenus Sargassum from Kampani coastal areas. Abbreviations: DH, discoid holdfast; CL, cauline leaf; PS. primary stem; $\mathrm{MB}$, main branch; $\mathrm{LMB}$, leaf of main branch; $2 \mathrm{~B}$, second branch; L2B, leaf of secondary branch; V2B, vesicle of secondary branch; 3B, tertiary branch; L3B, leaf of tertiary branch; V3B, vesicle of tertiary branch; 4B, fourth order branch; L4B, leaf of fourth order branch; V4B, vesicle of fourth order branch; R(5B), receptacle (modified from fifth order branch); SB (MB), stoloniferous branch modified from main branch, SB (2B), stoloniferous branch modified from secondary branch; $\mathrm{BH}$, branchlet with haptera, $\longrightarrow$ Leafy blade, $\longrightarrow=$ Transformed stoloniferous petiole along with midrib of the leaf, $\leftarrow$, NPP $=$ Newly propagated plantlet.

Branches of Sargassum herporhizum Setchell et Gardner and S. plagiophyllum C. Agardh sensu Mattio et Payri (= S. stolonifolium), in the present study, are normally smooth but these are covered with spines in S. polycystum C. Agardh. Morphological features of holdfast are not apparently different each other in Sargassum species observed in this study. Cauline leaves are found in some juvenile plants but these were lost in 
adult plants. In S. plagiophyllum C. Agardh and S. plagiophyllum C. Agardh sensu Mattio et Payri (= S. stolonifolium) main branches are terete and smooth but these are compressed to flattened in another two species. The younger plants of $S$. plagiophyllum C. Agardh sensu Mattio et Payri ( $=$ S. stolonifolium) are very similar to $S$. plagiophyllum C. Agardh. In adult plants, this species is different from S. plagiophyllum C. Agardh in having stolons. In addition, branches of S. plagiophyllum C. Agardh sensu Mattio et Payri ( $=$ S. stolonifolium) are slightly twisted but not in S. plagiophyllum C. Agardh. Leaves are oblong to ovoid in shape, cryptostomata are large and scatter on both sides of the midribs in S. plagiophyllum C. Agardh sensu Mattio et Payri (= S. stolonifolium) whereas these are oblong to linear-lanceolate in shape and cryptostomata are small and scattered or aligned on each side of the midribs in S. plagiophyllum C. Agardh. Male receptacle branches of two species are closely similar but female receptacle branches are slightly different between these two species. Female receptacles are compressed to terete in the former but these are compressed to triquetrous in the latter and pseudozygocarpic or holozygocarpic receptacles in the two species.

In the present study, leaves and vesicles showed morphological variabilities caused by polymorphisms and polyphenisms among populations of Kampani coastal areas but not in the receptacles as mentioned by Soe-Htun et al ${ }^{[4]}$., Kilar et al ${ }^{[5-7]}$., Mattio et $a l^{[8]}$. Monoecious receptacle branches are observed in S. swartzii (Turner) C. Agardh and S. cervicorne Greville while dioecious receptacle branches are found in S. plagiophyllum C. Agardh and S. plagiophyllum C. Agardh sensu Mattio et Payri (= S. stolonifolium).

Monoecious receptacle branches are flattened to compressed, twisted with spines on S. cervicorne Greville but slightly terete with small spines in S. swartzii (Turner) C. Agardh. Female receptacle branches of dioecious species, compressed with wavy outline in S. plagiophyllum C. Agardh sensu Mattio et Payri (= S. stolonifolium) while these are compressed to triquetrous in S. plagiophyllum C. Agardh. Male receptacle branches of S. plagiophyllum C. Agardh sensu Mattio et Payri (= S. stolonifolium) are closely similar in morphology to that of S. plagiophyllum C. Agardh. Stolons occur only in S. plagiophyllum C. Agardh sensu Mattio et Payri (=S. stolonifolium).

In Myanmar, the occurrence and distribution of the species diversity of Sargassum spp. along Kampani coastal areas is presented in Table 2. The numbers of species of Sargassum spp. were high in southern Kampani whereas those were low in Maungmagan. The genus Sargassum subgen Sargassum occurs both along the Rakhine and Tanintharyi Coastal Regions (Figure 54). A comparison of the latitudinal distribution ranges of the three species of Sargassum (S. swartzii (Turner) C. Agardh, S. cervicorne Greville and S. plagiophyllum C. Agardh (with or without stolons) are shown in Table 3. In the present study, Sargassum swartzii (Turner) C. Agardh was found from Southern Kampani (Lat. $14^{\circ} 02^{\prime} \mathrm{N}$, Long. $98^{\circ} 04^{\prime} \mathrm{E}$ ) to Ah-Le-Than-Kyaw (Lat. $20^{\circ} 50^{\prime} \mathrm{N}$, Long. $93^{\circ} 30^{\prime} \mathrm{E}$ ) with an intermediate distribution range but $S$. cervicorne Greville was encountered from Southern Kampani (Lat. $14^{\circ} 02^{\prime} \mathrm{N}$, Long. $98^{\circ} 04^{\prime} \mathrm{E}$ ) to Co Co Island (Lat. $14^{\circ} 10^{\prime} \mathrm{N}$, Long. $93^{\circ} 30^{\prime} \mathrm{E}$ ) through Thabawseik (Mwe Taung ${ }^{[39,40]}$ and Maungmagan ${ }^{[16]}$ with a narrowest distribution range. S. plagiophyllum C. Agardh (with or without stolons) distributed in nature from St.

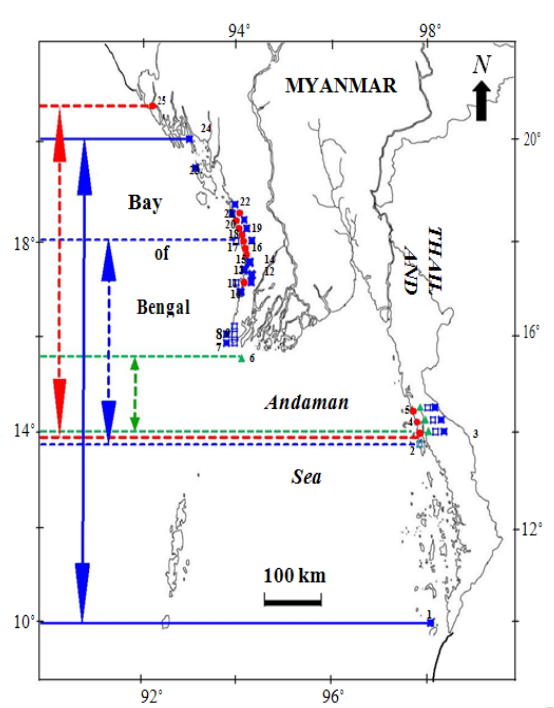

Figure 54: Map showing the distribution of Sargassum species along the coastal areas of Myanmar: 1. St. Luke I, 2. San Hlann, 3. Southern Kampani, 4. Thabawseik, 5. Maungmagan, 6. Co Co Island, 7. Mawtin Point, 8. Zee Gyaing, 9. Cape Nagraris, 10. Shwe Ya Gyaing, 11. Gwa Aw, 12. Yahaingkutoe, 13. Hlyaw Gaung Taung, 14. Maw Shwe Gyaing, 15. Mhaw Chye, 16. Kyaukme Taung, 17. Maung Shwe Lay Gyaing, 18. Kyauk Phone Gyi Mhaw, 19. Lonetha, 20. Ngapali, 21. Mazin, 22. Sing Gaung, 23. Yanbye I. (Kyaukoomaw and U Ba Saw's Pagoda), 24. Kyauk La Yaine Gyaing, 25. Ah-Le-Than-Kyaw, Symbols: - S. swartzii (Turner) Agardh, $\Delta$ S. cervicorne Greville, $\square$ S. plagiophyllum Agardh, $\square$ S. plagiophyllum sensu Mattio et Payri (= S. stolonifolium); - : Distribution range of $S$. swartzii, Distribution range of $S$. cervicorne, $-\cdots-$ - Distribution range of $S$. plagiophyllum, $\longleftrightarrow$ Distribution range of $S$. plagiophyllum $(=S$. stolonifolium).

Table 2: The occurrence and distribution of the species diversity of Sargassum spp. along Kampani coastal areas.

\begin{tabular}{|c|c|c|c|c|c|c|}
\hline \multirow{2}{*}{$\begin{array}{l}\text { Sr. } \\
\text { No. }\end{array}$} & \multirow[b]{2}{*}{ Species } & \multicolumn{5}{|c|}{ Locality } \\
\hline & & $\begin{array}{l}\text { Southern- } \\
\text { Kampani }^{1}\end{array}$ & $\begin{array}{c}\text { Thabaw- } \\
\text { seik }^{1}\end{array}$ & $\begin{array}{l}\text { Maung- } \\
\text { magan }^{2}\end{array}$ & $\begin{array}{c}\text { Thabaw- } \\
\text { seik }^{3}\end{array}$ & $\begin{array}{l}\text { Kam- } \\
\text { pani }^{4}\end{array}$ \\
\hline 1. & $\begin{array}{c}\text { S. swartzii } \\
\text { (Turner) C. } \\
\text { Agardh }\end{array}$ & + & - & - & - & + \\
\hline 2. & $\begin{array}{l}\text { S. cervicorne } \\
\text { Greville }\end{array}$ & + & + & + & + & - \\
\hline 3. & $\begin{array}{l}\text { S. plagiophyl- } \\
\text { lum C. Agardh }\end{array}$ & + & + & - & + & + \\
\hline 4. & $\begin{array}{l}\text { S. plagiophyl- } \\
\text { lum C. Agardh } \\
\text { (= S. stolonifo- } \\
\text { lium Phang et } \\
\text { Yoshida) }\end{array}$ & + & + & - & + & + \\
\hline & Total & 4 & 3 & 1 & 3 & 3 \\
\hline
\end{tabular}

Symbols: $(+)=$ present; $(-)=$ absent.Sources: $1=$ Present study $(2013) ; 2=$ Kyi Win and Kyaw Soe (1977); 3 = Soe- Htun et al. (2009); 4 = Myo Min Tun (2012) 
Table 3: The latitudinal distribution range of the genus Sargassum subgen. Sargassum along three Coastal Regions of Myanmar.

\begin{tabular}{|c|c|c|c|c|c|c|c|}
\hline \multirow{2}{*}{$\begin{array}{l}\text { Sr. } \\
\text { No. }\end{array}$} & \multirow{2}{*}{ Species } & \multicolumn{2}{|c|}{ TCR } & \multicolumn{2}{|c|}{$\mathrm{ACR}$} & \multicolumn{2}{|c|}{ RCR } \\
\hline & & From & To & From & To & From & To \\
\hline 1 & $\begin{array}{c}\text { Sargassum } \\
\text { swartzii } \\
\text { (Turner) C. } \\
\text { Agardh }\end{array}$ & $\begin{array}{c}\text { South- } \\
\text { ern } \\
\text { Kampa- } \\
\text { ni (Lat. } \\
14^{\circ} \\
02^{\prime} \mathrm{N}, \\
\text { Long. } \\
98^{\circ} \\
\left.04^{\prime} \mathrm{E}\right)\end{array}$ & $\begin{array}{l}\text { Maung- } \\
\text { ma- } \\
\text { gan } \\
\text { (Lat. 14 } \\
30^{\prime} \mathrm{N}, \\
\text { Long. } \\
98^{\circ} \\
\left.06^{\prime} \mathrm{E}\right)\end{array}$ & $\begin{array}{c}\text { No } \\
\text { Data }\end{array}$ & $\begin{array}{l}\text { No } \\
\text { Data }\end{array}$ & $\begin{array}{c}\text { Co Co } \\
\text { Island } \\
\text { (Lat. } \\
14^{\circ} \\
10^{\prime} \mathrm{N}, \\
\text { Long. } \\
93^{\circ} 30^{\prime} \\
\text { E) }\end{array}$ & $\begin{array}{c}\text { Ah-Le- } \\
\text { Than- } \\
\text { Kyaw } \\
\text { (Lat. } \\
20^{\circ} 50^{\prime} \\
\mathrm{N}, \\
\text { Long. } \\
93^{\circ} \\
\left.30^{\prime} \mathrm{E}\right)\end{array}$ \\
\hline 2 & $\begin{array}{c}\text { Sargassum } \\
\text { cervicorne } \\
\text { Greville }\end{array}$ & $\begin{array}{c}\text { South- } \\
\text { ern } \\
\text { Kampa- } \\
\text { ni (Lat. } \\
14^{\circ} \\
02^{\prime} \mathrm{N} \text {, } \\
\text { Long. } \\
98^{\circ} \\
\left.04^{\prime} \mathrm{E}\right)\end{array}$ & $\begin{array}{c}\text { Maung- } \\
\text { ma- } \\
\text { gan(Lat. } \\
14^{\circ} \\
30^{\prime} \\
\text { N,Long. } \\
98^{\circ} \\
\left.06^{\prime} \mathrm{E}\right)\end{array}$ & $\begin{array}{l}\text { No } \\
\text { Data }\end{array}$ & $\begin{array}{l}\text { No } \\
\text { Data }\end{array}$ & $\begin{array}{c}\text { Co Co } \\
\text { Island } \\
\text { (Lat. } \\
14^{\circ} \\
10^{\prime} \mathrm{N}, \\
\text { Long. } \\
93^{\circ} 30^{\prime} \\
\text { E) }\end{array}$ & \\
\hline 3 & $\begin{array}{l}\text { Sargas- } \\
\text { sumpla- } \\
\text { giophyllum } \\
\text { C. Agardh } \\
\text { (without } \\
\text { stolons) }\end{array}$ & $\begin{array}{c}\text { South- } \\
\text { ern } \\
\text { Kampa- } \\
\text { ni (Lat. } \\
14^{\circ} \\
02^{\prime} \mathrm{N} \text {, } \\
\text { Long. }^{\circ} \\
98^{\circ} 04^{\prime} \\
\text { E) }\end{array}$ & $\begin{array}{l}\text { Maung- } \\
\text { ma- } \\
\text { gan } \\
\left(\text { Lat. } 14^{\circ}\right. \\
30^{\prime} \mathrm{N}, \\
\text { Long. } \\
98^{\circ} 06^{\prime} \\
\text { E) }\end{array}$ & $\begin{array}{l}\text { No } \\
\text { Data }\end{array}$ & $\begin{array}{l}\text { No } \\
\text { Data }\end{array}$ & $\begin{array}{c}\text { Mawtin } \\
\text { Point } \\
\text { (Lat. } \\
16^{\circ} \\
04^{\prime} \mathrm{N}, \\
\text { Long. } \\
94^{\circ} 20^{\prime} \\
\text { E) }\end{array}$ & $\begin{array}{c}\text { Maung } \\
\text { Shwe } \\
\text { Lay } \\
\text { Gyaing } \\
\text { (Lat. } 18^{\circ} \\
21^{\prime} \mathrm{N}, \\
\text { Long. } \\
94^{\circ} 21^{\prime} \\
\text { E) }\end{array}$ \\
\hline 4 & $\begin{array}{c}\text { Sarga- } \\
\text { sumpla- } \\
\text { giophylum } \\
\text { C. Agardh } \\
\text { ensu } \\
\text { Mattio et } \\
\text { Payri (= S. } \\
\text { stolonifoli- } \\
\text { um) }\end{array}$ & $\begin{array}{c}\text { St. } \\
\text { Luke } \\
\text { Island. } \\
\text { (Lat. } \\
10^{\circ} \\
10^{\prime} \mathrm{N}, \\
\text { Long. } \\
98^{\circ} 15^{\prime} \\
\mathrm{E} \text { ) }\end{array}$ & $\begin{array}{c}\text { Maung- } \\
\text { magan } \\
\text { (Lat. } 14^{\circ} \\
30^{\prime} \mathrm{N} \text {, } \\
\text { Long. } \\
98^{\circ} 06^{\prime} \\
\text { E) }\end{array}$ & $\begin{array}{c}\text { No } \\
\text { Data }\end{array}$ & $\begin{array}{l}\text { No } \\
\text { Data }\end{array}$ & $\begin{array}{c}\text { Mawtin } \\
\text { Point } \\
\text { (Lat. } \\
16^{\circ} \\
04^{\prime} \mathrm{N}, \\
\text { Long. } \\
94^{\circ} 20^{\prime} \\
\text { E) }\end{array}$ & $\begin{array}{c}\text { Kyauk } \\
\text { La Yaine } \\
\text { Gyaing } \\
\text { (Lat. } 19^{\circ} \\
50^{\prime} \mathrm{N}, \\
\text { Long. }^{\circ} \\
\left.25^{\prime} \mathrm{E}\right)\end{array}$ \\
\hline
\end{tabular}

Abbreviations: $\mathrm{RCR}=$ The Rakhine Coastal Region; $\mathrm{ACR}=$ The Ayeyarwady Delta and the Gulf of Mottama (Martaban) Coastal Region; $\mathrm{TCR}=$ The Tanintharyi Coastal Region.

Luke I. (Lat. $10^{\circ} 10^{\prime} \mathrm{N}$, Long. $98^{\circ} 15^{\prime} \mathrm{E}$ ) to Kyauk La Yaine Gyaing (Lat.19 $50^{\prime} \mathrm{N}$, Long. 93 $25^{\prime} \mathrm{E}$ ), showing the widest range of distribution among the genus Sargassum in this study.

With regard to world distribution of 3 species of the genus Sargassum subgen. Sargassum in the present study, there are no records for these species of Sargassum along the coastal regions of the Atlantic Ocean (Figure 55). Sargassum swartzii (Turner) C. Agardh and S. cervicorne Greville distribute mainly in the Indian Ocean Regions (IOR) and eastern parts of the Pacific Ocean. On the other hand, S. plagiophyllum C. Agardh (with or without stolons) uniquely predominate along the coastal areas of the eastern part of the Indian Ocean except for the plants encountered in northern Gulf of California. In general, the ranges of phytogeographical distribution of all species of Sargassum normally occur along the Indo-Pacific regions except for the coastal region of the Atlantic Ocean.

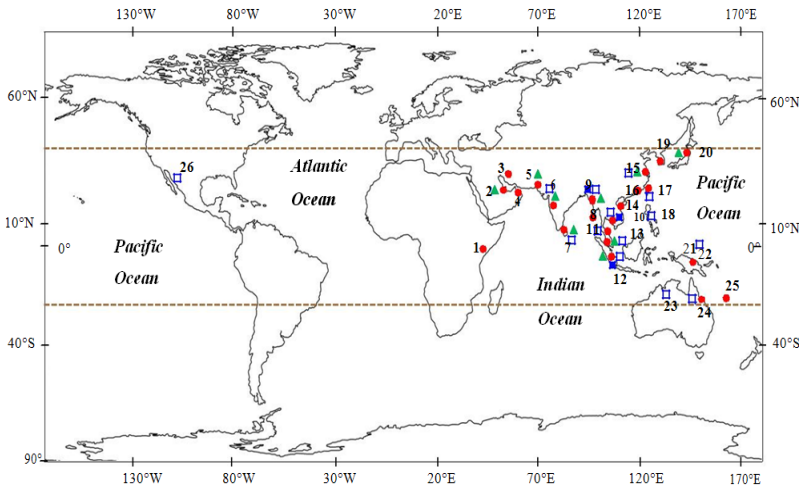

Figure 55: The phytogeographic distribution of Sargassum species: 1. Kenya, 2. Baharin, 3. Iran, 4. Persian Gulf, 5. Pakistan, 6. India, 7. Sri Lanka, 8. Andaman Islands and Nicobar Islands, 9. Myanmar, 10. Thailand, 11. Malaysia, 12. Indonesia, 13. Singapore, 14. Vietnam, 15. China, 16. Hong Kong, 17. Taiwan, 18. Philippines, 19. Korea, 20. Japan, 21. Federated States of Micronesia, 22. Papua New Guinea, 23. Australia, 24. Queensland, 25. New Caledonia, 26. Northern Gulf of Califonia. Symbols: $-S$. swartzii (Turner) C. Agardh, $\Delta$ S. cervicorne Greville, $\square$ S. plagiophyllum Agardh, - S.plagiophyllum Agardh sensu Mattio et Payri $(=S$. stolonifolium); Potential distribution range and Northernmost and southernmost recorded limits of Sargassum species.

Further studies on the cross fertilization, transplanting in different zones and the effects of ecological parameters such as wave actions, various substrates and habitats in different zones on the formations of stolons and newly propagated plantlets are still necessary to be worked out for the comfirmation of species between $S$. plagiophyllum C. Agardh (without stolons) and $S$. plagiophyllum sensu Mattio et Payri $(=S$. stolonifolium Phang et Yoshida) (with stolons).

\section{Conclusions}

The three species of Sargassum have been identified as Sargassum swartzii (Turner) C. Agardh and S. cervicorne Greville under Sargassum section Binderiana and S. plagiophyllum C. Agardh (with or without stolons) under Sargassum section Polycystae, belonging to the Subgenus Sargassum from Kampani coastal areas, Longlone Township of Taninthayi Region from October 2012 to March 2013.

Sargassum swartzii (Turner) C. Agardh and S. cervicorne Greville (Sargassum sect. Binderiana) revealed no formation of stolons. In contrast, S. plagiophyllum C. Agardh showed two types of plants with stolons and without stolons under Sargassum section Polycystae: S. plagiophyllum C. Agardh (without stolons) and S. plagiophyllum C. Agardh sensu Mattio et Payri (= S. stolonifolium Phang et Yoshida) (without stolons). It was suggested that further studies on the alternative transplanting of this species (with or without stolons) in various environments were still needed to be worked out to confirm the taxonomic status between S. plagiophyllum C. Agardh (without stolons) and $S$. plagiophyllum C. Agardh sensu Mattio et Payri (= S. stolonifolium Phang et Yoshida) (without stolons). S. cervicorne Greville was firstly reported from Kampani coastal areas. Among these, the latitudinall distribution range of S. plagiophyllum sensu Mattio et Payri (= S. stolonifolium Phang et Yoshida) (with stolons) is wider than that of the remaining species. All these species of Sargassum mostly occur along the coastal regions of the Indian and eastern parts of the Pacific Ocean. 


\section{Keys to the Species of Sargassum from Kampani Coastal} Areas

1a. Plants monoecious; branches are flattened to compressed without forming stolons .2

1b. Plants dioecious; branches are terete with or without stolons ...3

2a. Vesicles are ellipsoidal to spherical with pointed or a short leafy crown; receptacles are compressed with small spines at the apex .... S. swartzii

$2 b$. Vesicles are spherical with rounded apices; receptacles are flattened and twisted with spines...........S. cervicorne

3a. Plants without stolons; vesicles are ellipsoidal in shape; female receptacles are pseudozygocarpic.......Sargassum plagiophyllum

3b. Plants with stolons; vesicles are spherical to ellipsoidal in shape; female receptacles are pseudozygocarpic or holozygocarpic.......................S. plagiophyllum C. Agardh sensu Mattio et Payri (= S. stolonifolium Phang et Yoshida)

Acknowledgement: We are thankful to Dr. Htay Aung, Rector and Dr. Aung Myat Kyaw Sein and Dr. Zaw Win, Pro-Rectors of Mawlamyine University, for their encouragement and support throughout this work. We are extremely indebted to Dr. U. Min-Thein, Director (Retd), Myanmar Pharmaceutical Factory (MPF), Sagaing, Ministry of Industry (1), Myanmar for his invaluable guidance and constructive criticism on this study, and literature provided. We would like to express our sincere thanks to the local people and officials of Kampani Village for their kind helps during our field trips. Special thanks go to Daw Khin Khin Gyi and Daw Jar San, Demonstrators, Department of Marine Science, Mawlamyine University, for their helpful assistance during this study. The first author, Hsu Mon Oo wishes to thank her parents for their moral and financial supports, and understanding to her throughout this research work. Funding for this work from the Ministry of Education and the Department of Marine Science, Mawlamyine University is most appreciated.

\section{References}

1. Phillips, N. Biogeography of Sargassum (Phaeophyta) In The Pacific Basin. (1995) 107-144.

2. Guiry, M.D., Guiry, G.M. World-wide electronic publication, National University of Ireland, Galway (2013).

3. Mattio, L., Payri, C.E., Verlaque, M. et al. Taxonomic revision of Sargassum sect. Acanthocarpicae (Fucales, Phaeophyceae). (2010) Taxon 59(3): 896-904.

4. Soe-Htun, U., Yoshida, T. Studies on morphological variations in Sargassum cristaefolium C. Agardh (Phaeophyta, Fucales). (1986) Jap J Phycol (Sorui) 34(4): 275-281.

5. Kilar, J.A., Hanisk, M.D. Phenotypic variability in Sargassum polyceratium (Fucales, Phaeophyta). (1989) Phycologia 28(4): 491-500.

6. Kilar, J.A., Hanisk, M.D., Yoshida, T. On the expression of phenotypic variability: Why is Sargassum so taxonomically difficult? In: Abbott, I.A. (Ed.). Taxonomy of economic seaweeds with reference to some Pacific and Western Atlantic species. (1992a) California Sea Grant College 3: 95-177.

7. Kilar, J.A., Ajisaka, T., Hanisk, M.D., et al. A comparative study of Sargassum polyporum from the Ryukyu Is. (Japan) and S. polyceratium from the Florida Keys (United States). In: Abbott, I.A. (Ed.). Taxonomy of economic seaweeds with reference to some Pacific and Western Atlantic species. (1992b) California Sea Grant College 3: 119-132.
8. Mattio, L., Payri, C.E. 190 years of Sargassum Taxonomy, Facing the advent of DNA phylogenies. (2011) Bot Re 77(1): 31-70.

9. Reine, W.F.P.van., Trono, G.C. Jr. (Eds). Plant resources of SouthEast Asia. Cryptograms: Algae. (2002) Prosea Foundation Bogor Indonesia 15(1): 318.

10. Rizvi, M.A., Shameel, M. Biological activity and elementology of benthic algae from Karachi Coast. (2003) Pak J Bot 35(5): 717-729.

11. Arunkumar, K., Sivakumar, S.R., Rengasarmi, R. Review on bioactive potential in seaweeds (Marine microalgae): A special emphasis on bioactivity in seaweeds against plant pathogens. (2010) Asian Journal of Plant Sciences 9(5): 227-240.

12. Chanda, S., Dave, R., Kaneria, M. et al. Seaweeds: A novel, untapped sources of drugs from sea to combat infectious diseases. (2010) Current research technology and education topics in Applied Microbiology and Microbial Biotechnology A. Mendez-Vilas (Ed) Formatex 473-480.

13. Costa, L.S., Fidelis, G.P., Tells, C.B.S., et al. Antioxidant and Antiproloferative activities of Heterofucans from the seaweed Sargassum filipendula. (2011) Mar Drugs 9(6): 952-966.

14. Boonchum, W., Peeraporn, Y., Kanjanapoth, D., et al. Antioxidant Activity of some seaweed from the Gulf of Thailand. (2011) Int J Agric Biol 13(1): 95-99.

15. Khaled, N., Hiba, M., Asma, C. Antioxidant and Antifungal activities of Padina pavonica and Sargassum vulgare from the Lebanese Mediterranean Coast. (2012) Advances in Environmental Biology 6(1): 42-48.

16. Kyaw, Soe., Kyi, Win. Seaweeds for utilization. (1977) University Translation and Publication Department 2(168): 502

17. Soe-Htun. Studies on the genus Sargassum (Phaeophyta, Fucales) of Burma. (1984) Yangon University (Unpublished).

18. Soe-Htun, U., Mya Kyawt Wai., Soe, PaPa, Kyaw., et al. The morphotaxonomy and phytogeographical distribution of the species of Sargassum section Polycystae (Fucales, Phaeophyta) from Myanmar: Sargassum polycystum C. Agardh and S. plagiophyllum C. Agardh. (2012) Mawlamyine University Research Journal. 4(1): 215-233.

19. Agardh, C.A. Systema algarum. (1824) Xxxviii+312 Lunda [Lund]. 20. Agardh, J.G. Species genera at ordines algarum. (1848) Lund: Gleerup 1: 363.

21. Agardh, J.G. Species Sargassum Australiae descriptae et dispositae. (1889) Ofversith af Kongl. Svenska Vetenskaps-Adademiens Handlingar 23 (3): 133.

22. Reinbold, Y. 'Sargassum' in Weber van-Bosse: Liste des Algues du Siboga. (1913) Siboga Exp Mon LIX a: 150-174.

23. Grunow. Additaminta ad cognitionem Sargassorum. (1915-1916) Verhandlungen der Kaiserlich-Koniglichen Zoologisch-Botanischen Gesellschaft in Wien 65: 329-448; ibid. 66: 1-48, 136-185

24. Setchell, W.A. Hong Kong seaweeds IV Sargassaceae (1935) Hong Kong Nat Suppl (4): 1-24.

25. Yamada, Y. Notes on Sargassum from the southern parts of Japan (I) (1942) Journ of Jap Bot 18(7): 369-381.

26. Misra, J.N. Phaeophyceae in India. (1966) Indian Council of Agricultural Research 203.

27. Pham-Hoang Ho. Contributio a latude des algues littorals du Vietnam I: le Sargassum. Ann. (1967) Fac Sci Saigon 299-332.

28. Pham-Hoang Ho. Rong bien Vietnam Marine algae of South Vietnam. (1969) [vi] +558 pages, $67+224+88+119+2$ figures. Saigon 29. Tseng, C.K. Common seaweeds of China. (1983) Science Press Beijing 316: 149.

30. Yoshida, T. Japanese and Taiwanese species of Sargassum subgenus Sargassum. In: Abbott, I.A. (Ed.). Taxonomy of economic seaweeds with reference to some Pacific and Caribbean species (1988) California Sea Grant College 2: 5-21.

31. Noro, T. Abbott, I.A. A tentative identification of some specimens of Sargassum from the tropical south Pacific. In: Abbott, I.A. (Ed.). Taxonomy of economic seaweeds with reference to some Pacific species. (1994) California Sea Grant College 4: 33-34.

32. Tseng, C.K. Lu, B. Studies on the Glomerulate Sargassum of China: 
I. The series Binderiana. In: Abbott, I.A. (Ed.). Taxonomy of economic seaweeds with reference to some Pacific species. (1995a) California Sea Grant College 5: 67-74.

33. Tseng, C.K. Lu, B. Studies on the Glomerulate Sargassum of China: II. The series Swartzia. In: Abbott, I.A. (Ed.). Taxonomy of economic seaweeds with reference to some Pacific species. (1995b) California Sea Grant College 5: 75-92.

34. Ajisaka, T.A. Sargassum specimens from Singapore and Malaysia in the Herbarium of the Bishop Museum. In: Abbott, I.A. and McDermid, K.J. (Eds.). Taxonomy of economic seaweeds with reference to some Pacific species. (2002) California Sea Grant College 8: 77-88.

35. Wong, C.L., Ng, W.S., Phang, S.M. Taxonomic notes on Sargassum species (Sargassaceae, Phaeophyta) from Malaysia. In: Phang, S.W., Lewmanomont, K. and Lim, P.E. (Eds.). Taxonomy of Southeast Asian seaweeds. (2008) Institute of Ocean and Earth Science. University of Malaya, Monograph Series 2: 105-131.

36. Myo Min Tun. Studies on the marine benthic green and brown algae of Kampani coastal areas. (2012) Mawlamyine University (Unpublished).

37. Silva, P.C., Basson, P.W., Moe, R.L. Catalogue of the benthic marine algae of the Indian Ocean. (1996) Univ Calif Publ Bot 79: 1259

38. Soe-Htun, U., Mu Mu Aye., Soe Pa Pa Kyaw., et al. Distribution and potential uses of marine algae found along the Coastal Regions of Myanmar. Department of Marine Science. Mawlamyine University. (2007) Technical Repor 190.

39. Soe-Htun, U., Mya Kyawt Wai., Thida Nyunt., et al. Notes on some marine benthic algae of Gwa coastal areas: Phaeophyta (Brown algae). (2009a) Journal of Myanmar Academy of Arts and Science 7(5): 87113.

40. Soe-Htun, U., Mya Kyawt Wai., Thida Nyunt., et al. Chieklist, distribution and potential utilization of marine algae of Myanmar I: Chlorophyta (Green algae) and Phaeophyta (Brown algae). (2009b) Journal of Myanmar Academy of Arts and Science 7(5): 263-277.

41. Setchell, W.A. Hong Kong seaweeds. II. Sargassaceae. (1931) Hong Kong Nat Suppl 2: 237-253.

42. Soe-Htun, U. The seaweed resources of Myanmar. In: Critchley, A.T. and Ohno, M. (Eds.), Seaweed resources of the world. (1998) Kanagawa International Fisheries Training Center, Japan International Cooperation Agency (JICA) 99-105.

43. Coppejans, E., Prathep, A., Leliaert, F., et al. Seaweeds of Mu Ko Tha Lae Tai (SE Thailand): Methodologies and field guide to the dominant species. (2010) Biodiversity Research and Training Programm (BRT) Bangkok 274.

44. Myint Myint Cho. Small scale extraction of alginate compounds from some brown seaweeds of Myanmar. (2011) Mawlamyine Unversity (Unpublished).
45. Durairatnam, M. Contribution to the study of the marine algae of Ceylon. (1961) Bull Fish Res Stn 10: 1-181.

46. Boergesen, F. Some Indian green and brown algae especially from the shores of the Presidnecy of Bombay. III. (1933) J Indian Bot Soc 12(1): 1-6, 1-5.

47. Biswas, K., Shama, A.K. Sargassa of India. (1950) Seas J Roy Asiat Soc Bengal (Science) 16(1): 79-97, 1-3.

48. Modelo, R.B., Orosco, C.A., Nakahara, H. Et al. Brown algae (Phaeophyta) in the Palawan and Mindanao, Philippines. In: Umezaki, I. (Ed.). Scientific survey of marine algae and their resources in the Philippine Islands. (1989) The Oversea Research Project, Philippines (2): 29-34.

49. Tseng, C.K.., Lu, B. Studies on the Biserrulic Sargassum of China: IV. The Series Plagiophyllae Tseng et Lu. In: Abbott, I.A. and Mcdermid. K.J. (Eds.). Taxonomy of economic seaweeds with reference to some Pacific species. (2002) California Sea Grant College 8: 11-33.

50. Prathep, A., Pongparadon, S., Darakrai, A., et al. Diversity and distribution of seaweed at Khanom-Mu Ko Thale Tai National Park, Naknon Si Thammarat Province, Thailand. (2011) Songklanakarin J Sci Technol 33(6): 633-640.

51. Modelo, R.B. and Umezaki, I. Brown algae (Phaeophyta) in the Visayas, Philippines. In:Umezaki, I. (Ed.). Scientific survey of marine algae and their resources in the Philippine Islands. (1987) The Overseas Research Project, Philippines 1: 24-31.

52. Phang, S.M., Yoshida, T. Sargassum stolonifolium Phang et Yoshida sp. nov. from Penang Island, Peninsular Malaysia. In: Abbott, I.A (Ed.) Taxonomy of economic seaweeds with reference to some Pacific species. (1997) California Sea Grant College 6: 61-73.

53. Ajisaka, T.A., Phang, S.M., Yoshida, T. Preliminary report of Sargassum species collected from Malaysian coasts. In: Abbott, I.A. and McDermid, K.J. (Eds.). Taxonomy of economic seaweeds with reference to some Pacific species. (1999) California Sea Grant College 7: 23-41.

54. Ajisaka, T.A., Lewmanomont, K. Variations in the basal system and stolons of Sargassum stolonifolium in the Andaman Sea. In: Abbott, I.A. and McDermid, K.J. (Eds.). Taxonomy of economic seaweeds with reference to Pacific and other locations. (2004) California Sea Grant College 9: 57-72.

55. Noiraksar, T., Ajisaka, T. Taxonomy and distribution of Sargassum (Phaeophyceae) in the Gulf of Thailand. (2008) J Appl Phycol 20: 963977.

56. Setchell, W.A., Gardner, N.L. Expedition of the California Academy of Sciences of the Gulf of California in 1921. The marine algae. (1924) Proceedings of the Californian Academy of Science 12: 731-740.

57. Dawson, E.Y. The marine algae of the Gulf of California. (1944) Allan Hancock Pacific Exped 3(10): 187-452, 31-77. 